\title{
Sistem Layanan Pengaduan Masyarakat pada Balai Besar POM Kota Pontianak Berbasis Mobile
}

\author{
M. Alfin Mu'tashim ${ }^{\# 1}$, Hengky Anra ${ }^{\# 2}$, Heri Priyanto ${ }^{\# 3}$ \\ \#Jurusan Informatika Universitas Tanjungpura \\ Jl. Prof. Dr. Hadari Nawawi, Pontianak, Kalimantan Barat 78124 \\ ${ }^{1}$ alfintashimegmail.com \\ ${ }^{2}$ stmkomegmail . com \\ ${ }^{3}$ heripriyanto.stmtegmail.com
}

\begin{abstract}
Abstrak- Makanan kemasan dan obat yang merupakan salah satu kebutuhan manusia saat ini sudah banyak beredar di Indonesia. Peredaran makanan kemasan dan obat tersebut memerlukan perhatian dari pemerintah Indonesia sehingga pemerintah membentuk Badan Pengawas Obat dan Makanan (BPOM) untuk mengawasi peredaran tersebut. Selain peran BPOM, peran masyarakat sangat penting dalam membantu pengawasan obat dan makanan kemasan yang beredar di pasaran dengan memberikan pengaduan atau laporan kepada BPOM apabila menemukan obat dan makanan kemasan yang bermasalah. Berdasarkan hasil wawancara dengan Balai Besar POM Kota Pontianak bahwa saat ini pengaduan yang masuk dan diproses masih dilakukan secara konvensional melalui pengisian kertas formulir pengaduan hingga masyarakat mendapatkan jawaban dari pengaduannya tersebut. Untuk itu seiring dengan perkembangan teknologi aplikasi berbasis web dan mobile dengan platform Android, banyak cara yang dapat dilakukan untuk mempermudah masyarakat dalam memberikan pengaduan. Salah satu perangkat teknologi yang dapat digunakan adalah ponsel cerdas, maka dibuatlah aplikasi layanan pengaduan masyarakat pada Balai Besar POM Kota Pontianak yang dirancang menggunakan metode Waterfall dan menggunakan Unified Modeling Language (UML). Aplikasi tersebut dapat memudahkan masyarakat dalam memberikan pengaduan mengenai produk obat dan makanan yang beredar di Kota Pontianak, serta sistem yang dibangun bertujuan untuk membantu Balai Besar POM Kota Pontianak dalam memproses setiap pengaduan. Berdasarkan hasil pengujian, aplikasi ini sudah berjalan dengan baik pada perangkat smartphone Android. Hasil perhitungan Skala Likert diperoleh hasil $82,15 \%$ yang menerangkan bahwa penelitian ini dapat dikategorikan dengan kriteria berhasil.
\end{abstract}

Kata kunci- Sistem, BPOM, Layanan Pengaduan Masyarakat, Android, Waterfall, UML

\section{Pendahuluan}

Makanan termasuk kebutuhan dasar terpenting dan sangat esensial dalam kehidupan manusia, di samping dua kebutuhan lainnya yaitu sandang dan papan. Demikian pentingnya fungsi makanan bagi manusia, sehingga tanpa makanan manusia tidak akan bisa bertahan hidup [1].

Salah satu pendukung kebutuhan manusia lainnya selain makanan adalah obat yang berfungsi untuk menjaga kesehatan manusia. Obat merupakan zat yang digunakan untuk pencegahan dan penyembuhan penyakit serta pemulihan dan peningkatan kesehatan bagi penggunanya [2]. Setiap obat punya manfaat, namun juga mempunyai efek samping yang merugikan [2].

Produk obat dan makanan yang diedarkan dan dipasarkan di Indonesia perlu mendapatkan perhatian dari berbagai pihak, terutama untuk keamanan produk obat dan makanan itu sendiri. Untuk itu pemerintah membentuk suatu lembaga untuk mengawasi hal tersebut yaitu Badan Pengawas Obat dan Makanan (BPOM). Selain peran BPOM, peran masyarakat sangat penting dalam membantu pengawasan obat dan makanan yang beredar di pasaran. Masyarakat diharapkan mampu menjadi konsumen cerdas yang teliti sebelum membeli dan mengkonsumsi obat dan makanan.

Saat ini pengaduan di Balai Besar POM Kota Pontianak dilakukan secara manual melalui pengisian kertas formulir pengaduan di bagian bidang Infokom yang kemudian dilanjutkan ke pimpinan Balai Besar POM Kota Pontianak untuk mendapatkan disposisi yang selanjutnya diteruskan ke bidang-bidang di Balai Besar POM Kota Pontianak yang terkait dengan pengaduan tersebut. Setelah diproses dan mendapatkan hasil atau jawaban untuk pengaduan tersebut, maka hasil tersebut akan dikembalikan ke bidang Infokom untuk disampaikan kembali ke masyarakat yang memberikan pengaduan. 
Berdasarkan uraian di atas, proses pengaduan masih dilakukan secara konvensional yaitu menggunakan kertas, selain itu masyarakat diharuskan untuk datang ke kantor untuk melakukan pengaduan. Oleh karena itu sistem layanan pengaduan masyarakat pada Balai Besar POM Kota Pontianak ini dibangun untuk mempermudah pihak Balai Besar POM Kota Pontianak dalam mengelola pengaduan yang diterima oleh masyarakat dari pengaduan diterima, diproses, hingga didapatkan hasil proses tersebut yang selanjutnya jawaban dikirimkan kembali ke masyarakat yang mengirimkan pengaduan. Salah satu komponen dari sistem ini adalah aplikasi berbasis mobile yang bertujuan untuk digunakan oleh masyarakat untuk menyampaikan pengaduan dengan data yang lengkap tanpa harus datang ke Balai Besar POM Kota Pontianak.

\section{URAIAN PENELITIAN}

\section{A. Pengaduan}

Pengaduan adalah laporan yang mengandung informasi atau indikasi terjadinya penyalahgunaan wewenang, penyimpangan atau pelanggaran perilaku yang dilakukan oleh aparat pengadilan, yang berasal dari masyarakat, anggota instansi peradilan, instansi di luar pengadilan, maupun dari media massa dan sumber-sumber informasi lain yang relevan [3].

\section{B. Badan Pengawas Obat dan Makanan (BPOM)}

BPOM adalah lembaga pemerintah nonkementerian yang menyelenggarakan urusan pemerintahan di bidang pengawasan Obat dan Makanan, berada di bawah dan bertanggung jawab kepada Presiden melalui menteri yang menyelenggarakan urusan pemerintahan di bidang kesehatan, dan dipimpin oleh Kepala. BPOM mempunyai tugas menyelenggarakan tugas pemerintahan di bidang pengawasan Obat dan Makanan sesuai dengan ketentuan peraturan perundang-undangan. Obat dan Makanan sebagaimana dimaksud terdiri atas obat, bahan obat, narkotika, psikotropika, prekursor, zat adiktif, obat tradisional, suplemen kesehatan, kosmetik, dan pangan olahan [4].

\section{Waterfall}

Metode pengembangan yang digunakan dalam pembuatan sistem ini adalah metode Waterfall. Metode Waterfall adalah suatu model yang memberikan pendekatan sistematis dan berurutan bagi pengembangan perangkat lunak yang dimulai melalui proses analisis, desain, pengkodean, uji coba, dan pemeliharaan [5], [6]. Model Waterfall tersusun atas aktivitas-aktivitas berikut ini

1) Analysis (Analisis): Analisis yaitu merupakan tahap awal dimana dilakukan proses pengumpulan data, identifikasi masalah, usulan pemecahan masalah dan analisis kebutuhan sistem yang difokuskan untuk pembuatan aplikasi [6].

2) Design (Perancangan): Perancangan yaitu melakukan perancangan agar dapat menyediakan rancangan yang diharapkan. Pada tahap ini dilakukan
Context Diagram, Data Flow Diagram (DFD), Entity Relational Diagram (ERD), perancangan database, perancangan struktur menu serta perancangan layar aplikasi [6].

3) Code Generation (Pengkodean) : Pengkodean yaitu melakukan penerapan hasil rancangan ke dalam bentuk yang dapat dibaca dan dimengerti oleh komputer [6].

4) Test (Pengujian) : Pengujian yaitu program harus diuji coba yang difokuskan pada aktifitas pemastian bahwa semua perintah yang ada telah dicoba dan fungsi eksternal untuk memastikan bahwa dengan masukan tertentu suatu fungsi akan menghasilkan keluaran sesuai dengan yang dikehendaki [6].

\section{Android}

Android merupakan sistem operasi yang dikembangkan untuk perangkat mobile berbasis Linux. Pada awalnya sistem operasi ini dikembangkan oleh Android Inc. yang kemudian dibeli oleh Google pada tahun 2005.

Dalam usaha mengembangkan Android, pada tahun 2007 dibentuklah Open Handset Alliance (OHA), sebuah konsorsium dari beberapa perusahaan, yaitu Texas Instruments, Broadcom Corporation, Google, HTC, Intel, LG, Marvell Technology Group, Motorola, Nvidia, Qualcomm, Samsung Electronics, Sprint Nextel, dan TMobile dengan tujuan untuk mengembangkan standar terbuka untuk perangkat mobile. Pada tanggal 9 Desember 2008, diumumkan bahwa 14 orang anggota baru akan bergabung dengan proyek Android, termasuk PacketVideo, ARM Holdings, Atheros Communications, Asustek Computer Inc, Garmin Ltd, Softbank, Sony Ericsson, Toshiba Corp, dan Vodafone Group Plc [7].

Untuk membangun atau membuat aplikasi berbasis Android, terdapat dua cara. Pertama, kita harus memiliki perangkat telepon seluler yang berbasis Android langsung. Kedua, menggunakan emulator yang sudah disediakan oleh Google. Sebelum memulai membangun aplikasi berbasis Android, diperlukan beberapa perangkat, antara lain [8]:

- The Eclipse IDE

- Sun's Java Development Kit (JDK)

- The Android Software Developer's Kit (SDK).

- The Android Developer Tool (ADT).

- Plug-in Eclipse.

Android adalah sebuah sistem operasi yang berbasis java yang beroperasi pada kernel Linux 2.6. Sistem Android sangat ringan dan penuh fitur. Android sendiri bukanlah sebuah bahasa pemrograman, tetapi Android merupakan sebuah environment untuk menjalankan aplikasi. Android terdiri dari 3 elemen utama yaitu Operating System, Middleware, dan Key Application [9].

\section{E. RESTful Web Service}

REST atau Representational State Trasnfer merupakan salah satu jenis web service yang pertama kali diperkenalkan pada tahun 2000 oleh Roy Fielding [10]. REST merupakan standar dalam arsitektur web yang menggunakan protocol HTTP untuk pertukaran data [11]. 
Web service adalah salah satu bentuk sistem perangkat lunak yang didesain untuk mendukung interaksi mesin ke mesin melalui jaringan. Sistem web service memungkinkan sebuah fungsi yang ada di dalam web service dapat digunakan oleh aplikasi lain tanpa perlu mengetahui detail pemrograman yang terdapat didalamnya. Contoh implementasi dari web service antara lain adalah SOAP dan REST. Sistem yang menggunakan arsitektur dari REST dapat disebut dengan RESTful Web Service [12]. Penetapan indentifikasi terhadap resource dilakukan oleh Universal Resource Identifiers (URIs) atau Global ID. Resource diperkenalkan dengan format teks, JSON, atau XML. Pada umumnya, format yang digunakan adalah JSON dan XML [13].

\section{F. $M y S Q L$}

Referensi [14] menyebutkan MySQL adalah sebuah basis data yang mengandung satu atau jumlah tabel. Tabel terdiri atas sejumlah baris dan setiap baris mengandung satu atau sejumlah tabel. Tabel terdiri atas sejumlah baris dan setiap baris mengandung satu atau sejumlah tabel. Tipe data $M y S Q L$ adalah data yang terdapat dalam sebuah tabel berupa kolom-kolom yang berisi nilai dari data tersebut. Nilai data dalam kolom memiliki tipe sendiri-sendiri [14].

\section{G. Unified Modelling Language}

Untuk membantu dalam pengembangan perangkat lunak dikenal istilah pemodelan. Salah satu pemodelan yang saat ini paling banyak digunakan oleh pengembang perangkat lunak adalah Unified Modelling Language (UML). UML adalah standar bahasa yang sering digunakan dalam bidang industri untuk mendefinisikan requirement (kebutuhan), membuat analisis dan desain, serta menggambarkan arsitektur dalam pemrograman berorientasi objek [15].

1) Use Case Diagram: Use case diagram merupakan pemodelan untuk kelakuan (behaviour) sistem yang akan dibuat. Use case mendeskripsikan sebuah interaksi antara satu atau lebih aktor dengan sistem yang akan dibuat. Use case digunakan untuk mengetahui fungsi apa saja yang ada di dalam sebuah sistem dan siapa saja yang berhak menggunakan fungsi-fungsi tersebut [15].

2) Activity Diagram: Diagram aktivitas atau activity diagram menggambarkan workflow (aliran kerja) atau aktivitas dari sebuah sistem atau proses bisnis atau menu yang ada pada perangkat lunak. Perlu diperhatikan bahwa diagram aktivitas menggambarkan aktivitas sistem bukan apa yang dilakukan aktor, jadi aktivitas yang dapat dilakukan oleh sistem [15].

3) Class Diagram: Diagram kelas atau class diagram menggambarkan struktur sistem dari segi pendefinisian kelas-kelas yang akan dibuat untuk membangun sistem. Kelas memiliki apa yang disebut atribut dan method atau operasi. Atribut merupakan variabel-variabel yang dimiliki oleh suatu kelas. Operasi atau method adalah fungsi-fungsi yang dimiliki oleh suatu kelas [15].

4) Sequence Diagram: Diagram sekuen menggambarkan kelakuan objek pada use case dengan mendeskripsikan waktu hidup objek dengan message yang dikirimkan dan diterima antar objek. Menggambarkan diagram sekuen harus diketahui objek-objek yang terlibat dalam sebuah use case beserta metode-metode yang dimiliki kelas yang diinstansiasi menjadi objek itu [15].

\section{METODE PENELITIAN}

Langkah-langkah dalam penelitian yang dilakukan pada penelitian ini dapat dilihat pada Gambar 1 .

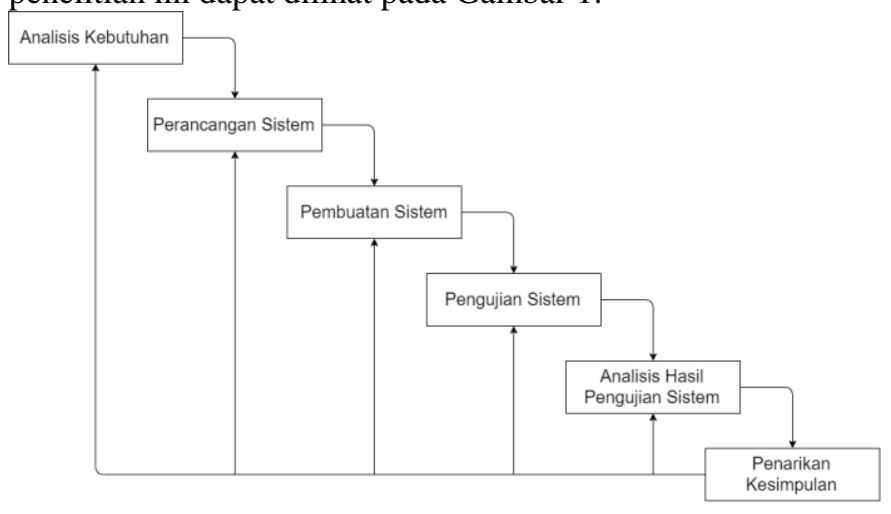

Gambar. 1 Diagram alir penelitian

\section{A. Analisis Kebutuhan}

Analisis Kebutuhan dilakukan untuk menganalisa kebutuhan yang akan digunakan untuk sistem. Setelah dianalisa, data-data yang diperlukan kemudian dikumpulkan. Pengumpulan data dilakukan dengan wawancara dengan Balai Besar POM Kota Pontianak.

Kebutuhan yang didapat dari hasil wawancara yang akan digunakan dalam sistem adalah teknis pengaduan, data form pengaduan, jenis-jenis pengaduan, dan proses bisnis sistem.

Teknis pengaduan yang digunakan meliputi SOP (Standard Operating Procedure) dari layanan pengaduan masyarakat. Sistem menggunakan aplikasi berbasis web dan aplikasi berbasis mobile. Pengguna dari masyarakat mengirimkan pengaduan berdasarkan data dari form pengaduan yang didapatkan, data tersebut yaitu identitas pelapor seperti nama, alamat, nomor telpon, dan melampirkan kartu identitas, selain identitas pelapor, juga terdapat data pengaduannya seperti nama produk, jenis produk, tanggal kadaluarsa, alamat pabrik, inti masalah, dan melampirkan foto atau gambar dari produk.

\section{B. Perancangan Sistem}

Perancangan sistem dilakukan untuk dapat mendokumentasikan aplikasi yang akan dibangun, serta mempermudah dalam pembuatan aplikasi. Perancangan sistem yang dibangun dalam penelitian ini terdiri dari:

- Perancangan arsitektur sistem,

- Perancangan flowchart sistem,

- Perancangan UML,

- Perancangan basis data (database), serta

- Perancangan antarmuka (interface) aplikasi.

Perancangan arsitektur yang dibangun dapat dilihat pada Gambar 2. 


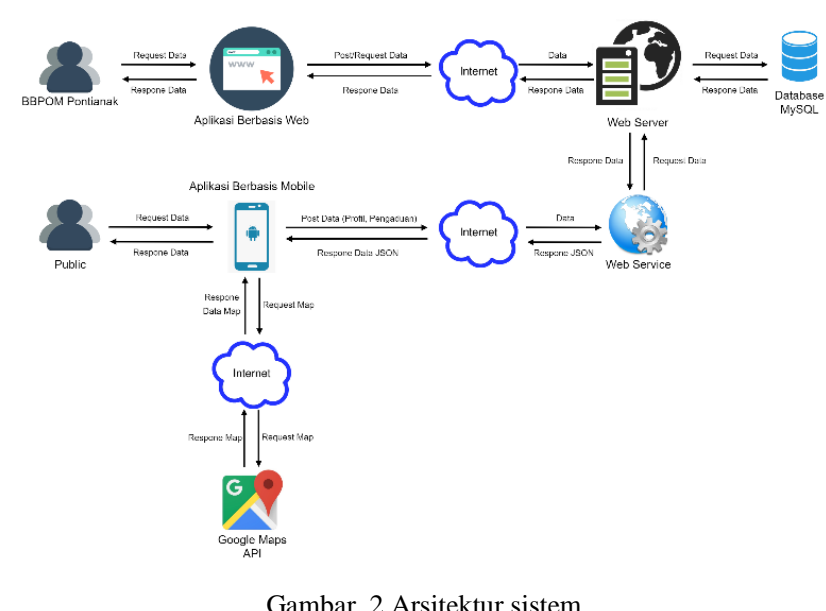

Berdasarkan Gambar 2 sistem terdiri dari dua user utama yaitu dari masyarakat yang menggunakan aplikasi berbasis mobile dan dari Balai Besar POM Kota Pontianak sebagai admin yang menggunakan aplikasi berbasis web. Pada petugas dari Balai Besar POM Kota Pontianak secara rinci terdapat dua pengguna yaitu super admin dan admin. Super admin dan admin adalah pengguna aplikasi berbasis website. Super admin merupakan pengguna yang dapat mengatur atau manajemen data yang akan ditampilkan pada halaman aplikasi Android. Admin merupakan pengguna yang akan menindaklanjuti pengaduan dari masyarakat. User yang berasal dari masyarakat dapat mengkases aplikasi berbasis Android yang kemudian memberikan laporan atau pengaduannya melalui aplikasi tersebut.

Masyarakat menggunakan Google Maps API untuk mengambil data lokasi dari lokasi pembelian. Melalui aplikasi Android juga, masyarakat mengirimkan pengaduan yang kemudian diterima oleh web server dan masuk ke basis data. Sistem ini menggunakan basis data MySQL dan dapat diakses selama semua pengguna memiliki koneksi internet agar pengguna dapat mengirimkan data untuk disimpan dan diakses kembali di basis data. Apabila user membutuhkan data dari sistem, maka data akan dikirim ke user ke web service untuk diubah menjadi dalam bentuk JSON, selanjutnya user akan menerima data yang telah disesuaikan ke antarmuka pada aplikasi pada smartphone Android.

Melalui aplikasi berbasis web, admin mengelola data pengaduan, berita, dan user. User ini mengirimkan dan meminta data kepada web server menggunakan koneksi internet menuju basis data, kemudian basis data melalui web server mengirim kembali data yang diperlukan kepada user melalui koneksi internet.

Adapun use case diagram dari sistem layanan pengaduan masyarakat ini dapat dilihat pada Gambar 3.

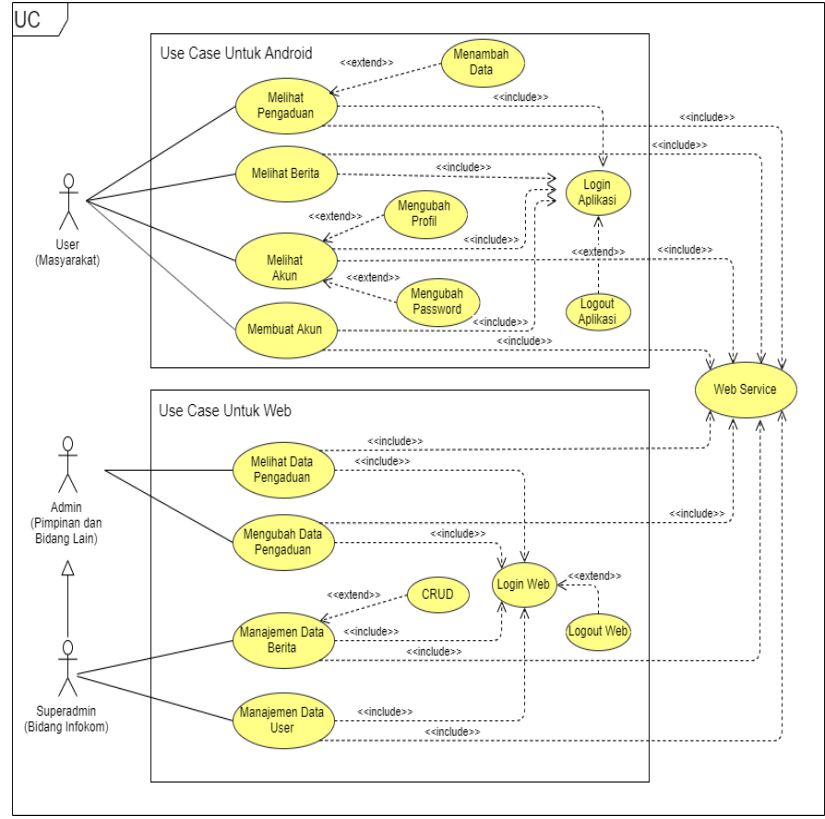

Gambar. 3 Use case diagram

Antarmuka merupakan tampilan dari suatu program aplikasi yang berperan sebagai sarana interaksi antara program dengan user. Struktur antarmuka dari sistem ini dapat dilihat pada Gambar 4.

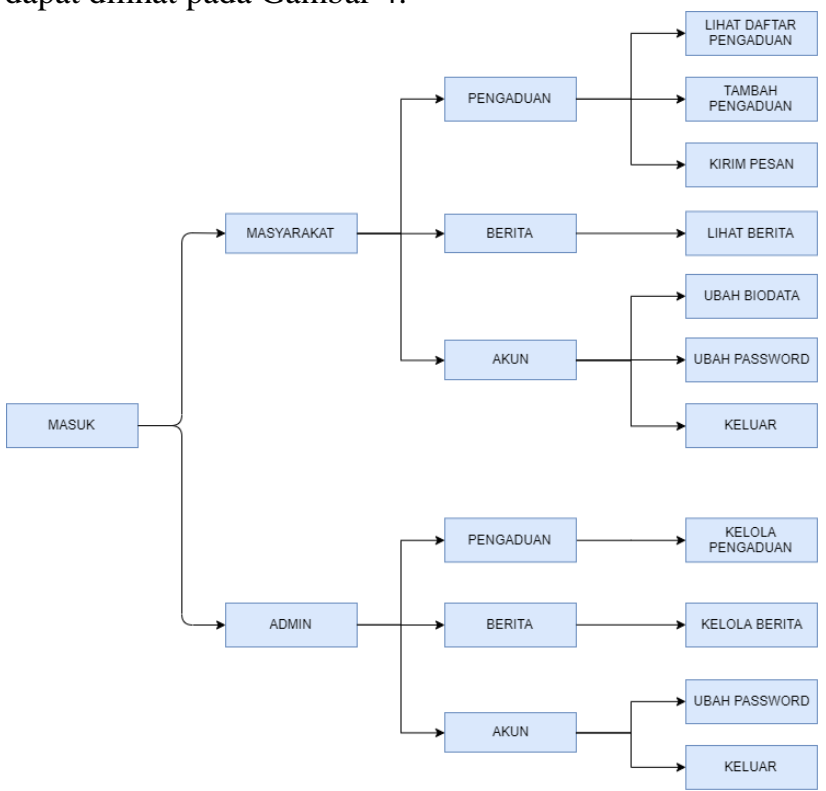

Gambar. 4 Struktur antarmuka sistem

\section{Pembuatan Sistem}

Setelah perancangan selesai, selanjutnya ialah membuat sistem yang terdiri dari aplikasi berbasis web dan aplikasi berbasis mobile. Pembuatan sistem dilakukan berdasarkan analisis kebutuhan dan perancangan sistem yang telah dilakukan. Pada aplikasi berbasis web menggunakan bahasa pemrograman PHP dan pada aplikasi berbasis mobile menggunakan Android Studio sebagai alat dalam pembuatan aplikasi. 


\section{Pengujian Sistem}

Setelah sistem yang dibuat telah selesai, kemudian sistem tersebut diuji menggunakan pengujian alpha dan pengujian beta.

\section{E. Analisis Hasil Pengujian Sistem}

Setelah sistem diuji, hasil dari pengujian tersebut di analisa untuk mendapatkan hasil berupa kesimpulan.

\section{F. Penarikan Kesimpulan}

Kesimpulan dirumuskan berdasarkan tahapan-tahapan yang telah dilakukan sebelumnya, serta berdasarkan analisis hasil pengujian yang telah dilakukan.

\section{HASIL DAN PEMBAHASAN}

\section{A. Hasil Perancangan}

Sistem yang dihasilkan dari hasil perancangan merupakan aplikasi yang terdiri dari aplikasi berbasis mobile Android dan aplikasi berbasis web. Aplikasi berbasis mobile digunakan oleh user dari masyarakat yang digunakan untuk mengakses informasi dan mengirimkan data pengaduan kepada Balai Besar POM Kota Pontianak. Pada aplikasi ini, user dapat membuat akun, memperbarui info profil, membaca berita, mengirimkan pengaduan, dan mendapatkan informasi dari hasil pengaduan yang telah diproses. Aplikasi berbasis web digunakan oleh user yang memiliki role Super Admin dan Admin dari pihak Balai Besar POM Kota Pontianak. Admin dapat manajemen data berita, manajemen data user, dan memproses data pengaduan yang diterima yang dilakukan oleh pimpinan dan bidang-bidang dari Balai Besar POM Kota Pontianak.

Gambar 5 merupakan halaman dashboard admin yang dapat diakses oleh admin setelah login. Admin dapat mengelola data master berita, data master user, dan data pengaduan dengan memilih menu yang ada pada sidebar.

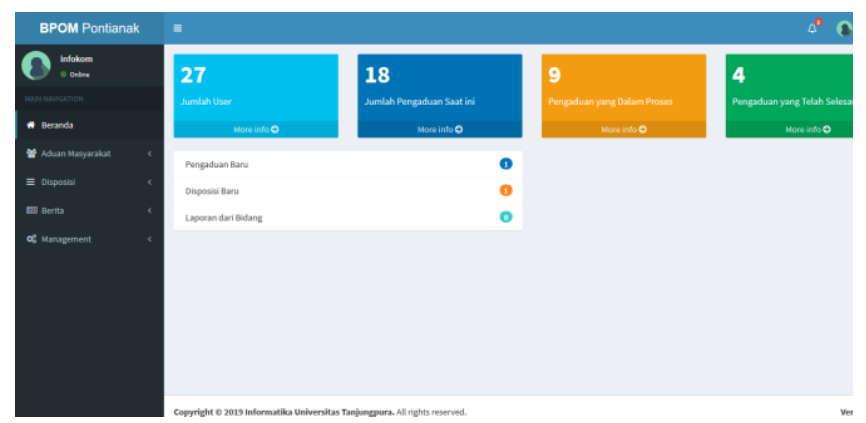

Gambar. 5 Halaman dashboard website admin

Gambar 6 merupakan halaman dashboard aplikasi berbasis mobile Android yang digunakan oleh masyarakat yang dapat diakses setelah berhasil melakukan login pada aplikasi. User dapat mengakses menu pegaduan, berita, dan akun.
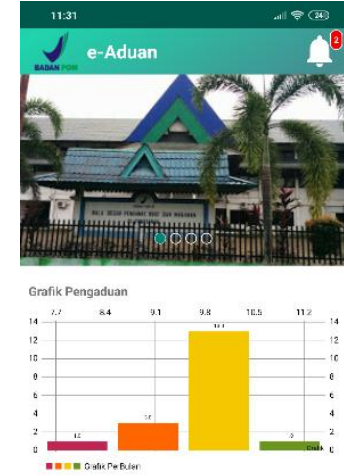

(1)

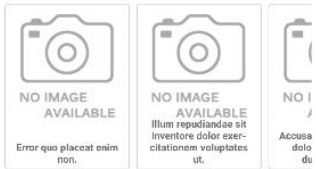

$\underset{\text { Beranda }}{\text { A }}$ 自

Gambar. 6 Halaman dashboard android

Gambar 7 merupakan halaman dari menu pengaduan yang menampilkan daftar pengaduan yang pernah dikirimkan oleh user tersebut. Warna hijau tua menandakan pemberitahuan bahwa status dari pengaduan tersebut telah diperbarui oleh admin.
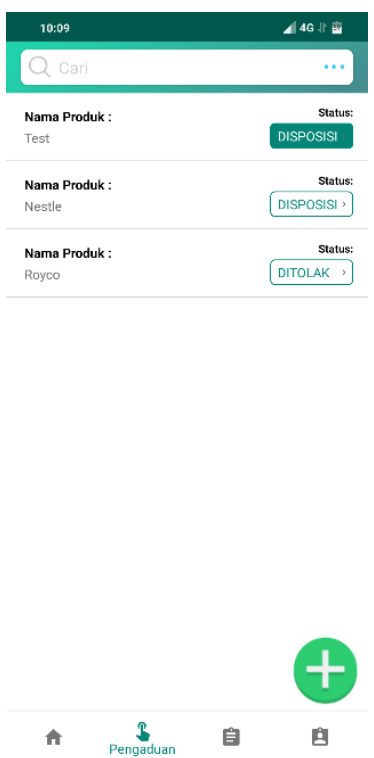

Gambar. 7 Halaman menu pengaduan

Gambar 8 merupakan halaman form pengaduan yang akan diisi oleh user apabila akan mengirimkan pengaduan. User diwajibkan untuk mengisi kolom nama produk, tanggal kadaluarsa, nama pabrik, tanggal guna, lokasi beli, isi pengaduan atau pertanyaan, dan menyertakan gambar atau foto. Apabila data sudah lengkap, maka pengaduan dapat dikirim. 


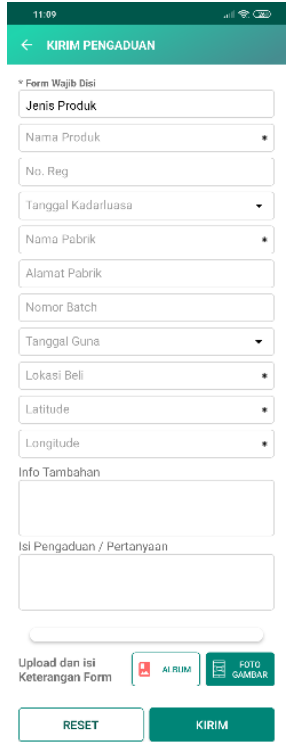

Gambar. 8 Halaman form pengaduan

Gambar 9 merupakan halaman detail aduan pada aplikasi berbasis mobile Android yang telah dikirim oleh user. Pada halaman ini menampilkan data-data dari form yang diisi oleh $u s e r$, status saat ini dari pengaduan tersebut, dan kolom percakapan antara user masyarakat dan Balai Besar POM Kota Pontianak.

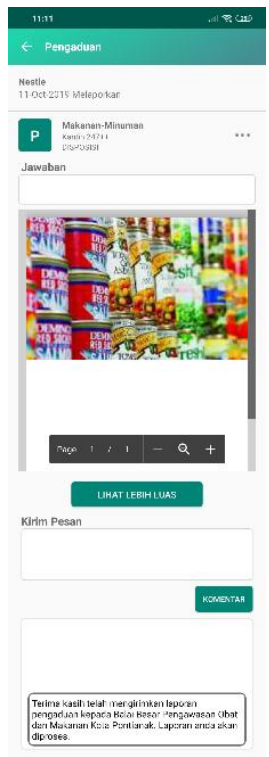

Gambar. 9 Halaman detail aduan

\section{B. Pengujian Sistem}

Setelah sistem yang dibuat telah selesai, kemudian sistem tersebut diuji menggunakan pengujian alpha dan pengujian beta.

Pengujian Alpha dilakukan pada aplikasi berbasis mobile dengan menggunakan BitBar Testing. Aspek yang diuji ialah fungsionalitas, performa, dan penggunaan memori. Pengujian dilakukan dalam empat perangkat yaitu
Motorola Google Nexus 6 Android versi 7.1.1 dan versi 6.0.1, LG Google Nexus 5 D820, dan LG Google Nexus 5.

Gambar 10 merupakan hasil pengujian analisis yang dilakukan oleh sistem BitBar didapatkan hasil 100\%, menyatakan bahwa seluruh metode di dalam aplikasi dapat berjalan. Selanjutnya yaitu pengujian tahapan tanpa mengalami error didapatkan hasil pengujian yaitu $100 \%$ yang menunjukkan seluruh tahapan yang dilakukan aplikasi berjalan tanpa gangguan.

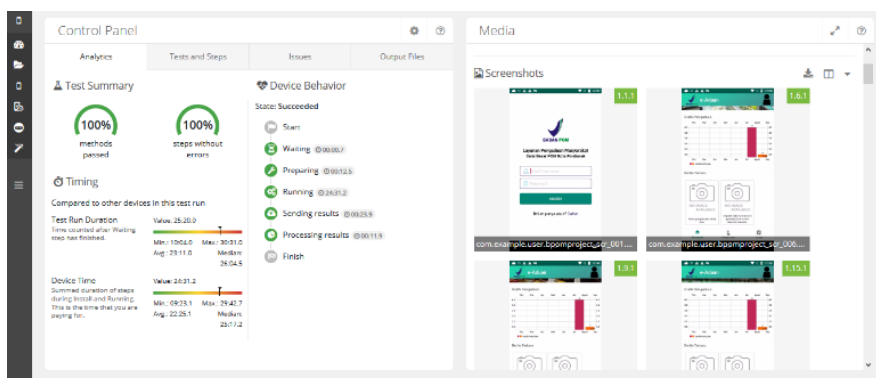

Gambar. 10 Hasil pengujian analisis

Gambar 11 merupakan hasil pengujian performa atau penggunaan memori dan CPU.

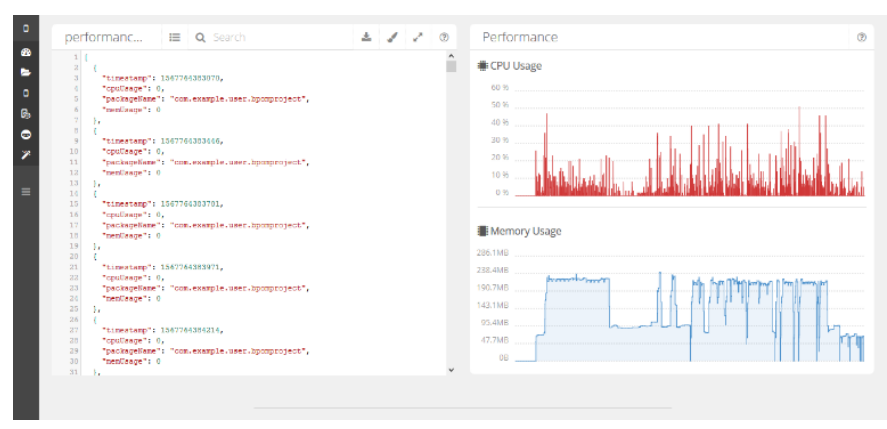

Gambar. 11 Hasil pengujian performa

Pengujian Beta dilakukan menggunakan metode Kuesioner. Pengujian ini digunakan untuk menguji tingkat penerimaan pengguna terhadap sistem dengan cara memberikan beberapa pertanyaan tertulis kepada responden untuk dijawab. Kuesioner dibagikan kepada 30 responden yang terdiri dari 25 orang dari masyarakat dan 5 orang dari pihak Balai Besar POM Kota Pontianak. Hasil kuesioner dapat dilihat pada Gambar 12.

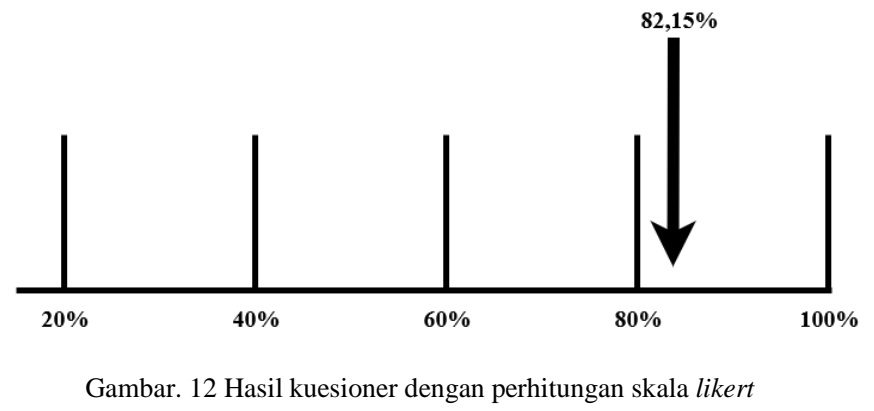

\section{Analisis Hasil Pengujian Sistem}

Setelah sistem diuji, hasil dari pengujian tersebut di analisa untuk mendapatkan hasil berupa kesimpulan. 
1. Hasil pengujian fungsional yang dilakukan oleh sistem oleh perusahaan Bitbar menunjukkan semua fungsi yang ada dalam aplikasi dapat berjalan semua dengan lancar.

2. Hasil pengujian memori dan cpu usage yang dilakukan oleh sistem dari perusahaan Bitbar menunjukkan aplikasi layanan pengaduan menggunakan banyak memori untuk menjalankan aplikasi.

3. Berdasarkan hasil kuesioner, secara umum responden menerima baik aplikasi layanan pengaduan dalam penelitian yang dilakukan.

4. Berdasarkan hasil kuesioner, secara umum responden dapat menjalankan aplikasi layanan pengaduan dengan lancar.

5. Berdasarkan hasil kuesioner, secara umum responden menyukai tampilan antarmuka, aplikasi layanan pengaduan.

6. Berdasarkan hasil kuesioner, mendapatkan kesimpulan bahwa aplikasi layanan pengaduan dapat membantu masyarakat dalam mengirimkan pengaduan kepada Balai Besar POM Kota Pontianak melalui aplikasi dan dinilai berhasil.

7. Hasil pengujian kuesioner yang diukur dengan Perhitungan Skala Likert menunjukkan responden menilai aplikasi yang dibagun dengan "sangat baik" dengan skor presentase $82,15 \%$.

\section{KESIMPULAN}

Berdasarkan hasil analisis dan pengujian terhadap sistem layanan pengaduan masyarakat, maka dapat ditarik kesimpulan sebagai berikut:

1. Aplikasi layanan pengaduan masyarakat ini telah dirancang dan dibuat dengan baik serta berjalan dengan lancar dalam perangkat Android dengan menggunakan Bitbar Testing. Melalui kuesioner aplikasi juga telah diterima dengan baik oleh masyarakat dan Balai Besar POM Kota Pontianak yang hasil pada kuesioner dihitung dengan menggunkan Skala Likert.

2. Penerapan aplikasi layanan pengaduan pada masyarakat dan Balai Besar POM Kota Pontianak dinilai berhasil yang ditunjukkan berdasarkan pada perhitungan Skala Likert yang berasal dari kuesioner yang diberikan kepada 30 responden untuk menilai aplikasi. Total presentase yang didapat dari 13 pertanyaan adalah $82,15 \%$ yang artinya mempunyai nilai "sangat baik".

3. Aplikasi layanan pengaduan yang dibangun sebagai media komunikasi antara masyarakat dan Balai Besar POM Kota Pontianak dalam pelayanan pengaduan yang dikirim masyarakat berjalan dengan baik berdasarkan pengujian oleh sistem Bitbar Testing yaitu $100 \%$ metode berjalan dengan baik tanpa error dalam perangkat Android dengan versi 5.0 (Lollipop) hingga versi 7.1.1 (Nougat) dengan berbagai ukuran resolusi layar.

\section{REFERENSI}

[1] Irahmani, "Rancang Bangun Aplikasi Pengecekan Keamanan Produk Makanan Berdasarkan Aturan Badan Pom Dengan Menggunakan Barcode Berbasis Android," Universitas Islam Negeri Alauddin, 2016.

[2] Badan POM, "Materi Edukasi Tentang Peduli Obat dan Pangan Aman," 2015. [Online]. Available: https://www.pom.go.id/files/2016/brem.pdf. [Accessed: 09-Nov2019].

[3] Republik Indonesia, "Surat Keputusan Ketua Mahkamah Agung No. 076/KMA/SK/VI/2009 Tentang Pedoman Pelaksanaan Penanganan Pengaduan di Lingkungan Lembaga Peradilan," 2009. [Online]. Available: https://ptun-jakarta.go.id/wpcontent/uploads/file/layanan_publik/pengaduan_layanan_publik/sk _pedoman_penanganan_pengaduan/SK KMA No 076 KMA SK VI 2009 Tentang Pedoman Pelaksanaan Penanganan Pengaduan Di Lingkungan Lembaga Peradilan.pdf. [Accessed: 09-Nov-2019].

[4] Republik Indonesia, "Peraturan Presiden Republik Indonesia No. 80 Tahun 2017 Tentang Badan Pengawas Obat dan Makanan," 2017. [Online]. Available: http://sipuu.setkab.go.id/PUUdoc/175299/Perpres Nomor 80 Tahun 2017.pdf. [Accessed: 09-Nov-2019].

[5] R. S. Pressman, Software Engineering A Practitioner's Approach Fifth Edition, 5th ed. New York: McGraw-Hill Companies, Inc., 2001.

[6] D. Ramdani, Partono, and C. Slamet, "Pengembangan Aplikasi Presensi di PT. Inti Bandung Berbasis Desktop Application," J. Algoritm., vol. 11, no. 1, p. 2, 2014.

[7] E. Maiyana, "Pemanfaatan Android Dalam Perancangan Aplikasi Kumpulan Doa," J. Sains dan Inform., vol. 4, no. 1, pp. 54-65, 2018.

[8] A. Elian, A. M. S., and H. Studiawan, "Layanan Informasi Kereta Api Menggunakan GPS, Google Maps, dan Android," J. Tek. POMITS, vol. 1, no. 1, pp. 1-6, 2012.

[9] M. R. Fadha and Y. Hendra, "Pengenalan Sekolah MTsN Kutablang Menggunakan Augmented Reality Berbasis Android," J. Umuslim, pp. 119-124, 2016.

[10] R. T. Fielding, "Architectural Styles and the Design of Networkbased Software Architectures," University of California, 2000.

[11] L. Richardson and S. Ruby, RESTful Web Services, 1st ed. 1005 Gravenstein Highway North, Sebastopol, CA 95472: O’Reilly Media, Inc., 2007.

[12] C.-J. Su and C.-Y. Chiang, "Enabling successful Collaboration 2.0: A REST-based Web Service and Web 2.0 technology oriented information platform for collaborative product development," Comput. Ind., 2012.

[13] A. Rahmatulloh, H. Sulastri, and R. Nugroho, "Keamanan RESTful Web Service Menggunakan JSON Web Token (JWT) HMAC SHA512," J. Nas. Tek. Elektro dan Teknol. Inf., vol. 7, no. 2, 2018.

[14] Y. Kustiyahningsih and D. Rosa, Pemrograman Basis Data Berbasis WEB Menggunakan PHP dan Mysql. Yogyakarta: Graha Ilmu, 2011.

[15] R. A. Sukamto and M. Shalahuddin, Rekayasa Perangkat Lunak Terstruktur dan Berorientasi Objek. Bandung: Informatika, 2014. 